\title{
Anti-N-methyl-D-aspartate receptor encephalitis in China
}

\author{
Li Li ${ }^{1}$, Cheng-Bin Wang ${ }^{2}$, Gang Zhao ${ }^{1}$ \\ ${ }^{1}$ Department of Neurology, Xijing Hospital, Fourth Military Medical University, Xi'an 710032, Shaanxi, China. \\ ${ }^{2}$ Department of Clinical Medicine, Fourth Military Medical University, Xi'an 710032, Shaanxi, China.
}

\section{A B S T R A C T}

$\mathrm{N}$-methyl-D-aspartate receptors (NMDARs) are mainly distributed in the central nervous system, and play important roles in the mechanisms of learning and memory. A newly discovered disease caused by autoantibody to NMDAR has been described, and is called anti-NMDAR encephalitis. Patients with this disease often suffer from mental disorders, seizures and other encephalitis-like symptoms. Accumulated data suggests that the severity of the disease makes early diagnosis very important. Accurately detecting the autoantibody to NMDAR is considered to be the gist of diagnosis. Good prognosis is predicted in most patients, when treated properly. Immunotherapy is preferred in most cases. In China, this disease has been reported only for a few years, but sporadic case reports are also helpful for profiling.

Key words: Encephalitis, N-methyl-D-aspartate, therapy

\section{INTRODUCTION}

\section{$\mathrm{N}$-methyl-D-aspartate}

N-methyl-D-aspartate(NMDA) is an artificially synthesized amino acid with a similar structure to glutamate, and can activate a certain type of glutamate-receptor located in postsynaptic membrane. High-dose NMDA could cause neuronal death by inducing excitotoxicity, and was used in behavioral neuroscience studies. Subsequently, low-dose NMDA was used to investigate the roles of glutamate and glutamate-receptor pathway in the central nervous system (CNS). ${ }^{[1]}$

Glutamate-receptor and N-methyl-D-aspartate receptor Glutamate-receptors in the CNS can be classified into two classes. One class is metabotropic glutamate-receptors coupled with a type of G-protein, whose activation mediates signal transduction cascade based on second

\begin{tabular}{|c|c|}
\hline \multicolumn{2}{|c|}{ Access this article online } \\
\hline Quick Response Code: & \\
\hline & $\begin{array}{l}\text { Website: } \\
\text { www.nnjournal.net }\end{array}$ \\
\hline & $\begin{array}{l}\text { DOI: } \\
10.4103 / 2347-8659.135571\end{array}$ \\
\hline
\end{tabular}

message to produce a slow physiological reaction. Another class is ionotropic glutamate-receptors (iGluRs) that constitute ligand-gated ion channel complex and mediate transduction of rapid physiological signals. Based on agonist preference, iGluRs can be categorized into three different groups. Receptors that can be activated by the synthetic agonist NMDA are called NMDA receptors (NMDARs) or NMDA-GluRs to understand their nature better. The other two groups are $\alpha$-amino-3-hydroxy-5-methyl-4-isoxazolepropionic acid (AMPA) receptors and kainate receptors. ${ }^{[2]}$

\section{Structure and physiological features of NMDA receptor}

NMDA receptor is a tetramer, which is composed of three subunits: NR1, NR2, and NR3. In mammalian neural tissues, the functional NMDARs contain at least NR1 and NR2 subunits, in which NR1 functions as the ion channel, NR2 possesses regulatory function for the receptor, and NR3 could act as the regulatory subunit. ${ }^{[3]}$ NMDARs are highly permeable for $\mathrm{Ca}^{2+}$, which acts as the second message to regulate some cellular signal transduction pathways. NMDARs are also important for neurons to maintain normal function and morphology. The normal physiological level of $\mathrm{Mg}^{2+}$ blocks NMDAR, so its biological activity relies on a certain degree of

Corresponding Author: Dr. Li Li, Department of Neurology, Xijing Hospital, Fourth Military Medical University, Xi'an 710032, Shaanxi, China. E-mail: lili@fmmu.edu.cn 
excitatory postsynaptic potentials, which can remove the $\mathrm{Mg}^{2+}$ block. Glycine and its analog D-serine can amplify the response of NMDARs to activate them together with glutamate. ${ }^{[4]}$

\section{Location of NMDA receptor}

NMDA receptors are mainly distributed in the CNS, and contribute to excitatory synaptic transmission. However, NMDARs are also expressed in the peripheral nervous system (PNS), for example, in the peripheral terminals of primary afferent nerves innervating the colon. ${ }^{[5]}$ NMDARs in PNS contribute to nociceptive stimulus, pain in facial muscles, and edema. Regions of the brain that prominently express NMDARs include hippocampus, dentate gyri, forebrain cortex, anterior cingulate cortex, and piriform cortex. Other areas such as corpus striatum, thalamus, and granule cells in the cerebellum also express high levels of NMDARs. Early studies had shown that NMDARs were mainly located in the postsynaptic membrane, especially in the postsynaptic density (PSD), for example, in the dendritic spine in excitatory neurons. ${ }^{\left[{ }^{[6]}\right.}$ However, recent research has indicated a more diverse distribution of NMDARs not only in PSD, but also in extra-PSD, presynaptic, and extra-synaptic regions. ${ }^{[7]}$ Typical examples of extra-synaptic NMDARs are in cerebellum astrocytes and retina ganglion. Factors that influence the activation of extra-synaptic NMDARs include the location and activity of neurons, the transporter in astrocytes, and glutamate spillover in synapses. ${ }^{[8]}$

\section{Functions of NMDA receptor}

NMDA receptors are involved in the development of the nervous system, including the survival of neurons, maturation of dendrites and axons, synaptic plasticity, and formation of neural circuits. In addition, long-term potentiation effect mediated by NMDARs is one of the basic mechanisms in learning and memory. ${ }^{[9]}$ It has been proven that over-activation of NMDARs is a potential mechanism for the occurrence of seizures, dementia and stroke, while the under-activation of NMDARs is involved in schizophrenia-like symptoms. ${ }^{[10,11]}$ In addition, NMDARs are known to mediate central sensitization in the pathogenesis of chronic pain after nociceptive stimulus. ${ }^{[12]}$ Therefore, NMDARs play a very important role in CNS.

\section{Factors regulating NMDA receptor activity}

The activity of NMDARs is regulated by several factors. Glycine can amplify the response of NMDARs to glutamine through allosteric effect after binding to NR1 subunit. Polyamines can also potentiate the response of NMDARs to glutamine, while zinc ion can block this effect. Several agonists and antagonists have been developed for laboratory research or used as tools in the discovery of new drugs targeting NMDARs such as, D-serine, L-alanine as agonists, and amantadine, ketamine, methoxetamine as antagonists.

\section{Discovery of anti-NMDA receptor encephalitis}

Several cases of neural deficiency accompanied with teratoma were seen from 1997 to 2004. ${ }^{[13]}$ In 2005, Vitaliani et al. ${ }^{[14]}$ analyzed four patients diagnosed with paraneoplastic encephalitis and five patients who were reported having similar symptoms. They found that all the patients were females, and had teratoma. Most of the patients experienced changes in their personalities, loss of short-term memory, seizures, central hypoventilation, and illusions. Abnormal immune systems were found in all patients. ${ }^{[14]}$ Two years later, Dalmau et al. ${ }^{[15]}$ found that serum and cerebrospinal fluid (CSF) samples from these patients showed positive immunochemistry reaction with the rat hippocampus. Finally, they found an antibody that could bind to NMDAR expressed in cultured neurons or human embryonic kidney 293 (HEK 293) cell membranes in an unregulated manner. The term "anti-NMDAR encephalitis" was coined in that year. In 2008, the antibody was shown to bind to the NR1 subunit of NMDAR, resulting in the loss of its ion channel function. ${ }^{[16]}$

The first case of limbic encephalitis with teratoma was reported in 2009. Since the antibody could not be detected in serum or CSF, it could not be ascertained whether this case was an anti-NMDAR encephalitis. ${ }^{[17]}$

Probable mechanism of anti-NMDA receptor encephalitis synaptic plasticity

The autoantibody in the patient's CSF could reduce the NMDAR clusters in the synapse by binding, cross-linking and internalization. The reduction was reversible, and dependent on the titer of the autoantibody. Integrality of the neurons, synapses, receptors or proteins in the synapse was not harmed by the antibody. The density of the NMDAR clusters could recover four days after deletion of the autoantibody. ${ }^{[18]}$

Progress after discovery of anti-NMDA receptor encephalitis After the discovery of anti-NMDAR encephalitis, the diagnosis of some clinical signs and syndromes such as catatonia, subacute confusion of memory, seizures, abnormal movements and limbic encephalitis had to be changed. Other forms of encephalitis mediated by autoantibodies against synaptic receptors were found later, such as anti-AMPA receptor, 
anti-gamma-aminobutyric acid-B receptor and leucine-rich, glioma-inactivated $1 .{ }^{[19-21]}$

Here, we reviewed all the cases reported with details and made a profile about anti-NMDAR encephalitis in China.

MANIFESTATION, DIAGNOSIS, TREATMENT, AND PROGNOSIS OF ANTI-NMDA RECEPTOR ENCEPHALITIS

\section{Epidemiological features}

The precise data on the incidence of anti-NMDAR encephalitis is still unknown. However, it is believed to be the most common paraneoplastic syndrome. A retrospective analysis found that anti-NMDAR encephalitis accounts for $1 \%$ of all encephalitis cases of unknown origin. ${ }^{[22]} \mathrm{A}$ prospective study found that anti-NMDAR encephalitis accounts for $4 \%$ of the reasons leading to encephalitis in Britain, and is the second most common immune-related encephalitis after acute disseminated encephalomyelitis, and the most common antibody-related encephalitis. ${ }^{[23]}$ Moreover, the incidence of anti-NMDAR encephalitis is increasing. ${ }^{[23]}$

In 2008, Dalmau et al. ${ }^{[16]}$ analyzed 100 consecutive patients and found that 91 of them were females with a mean age of 23 years. About 59\% (58/98) of patients were paraneoplastic, and teratoma was the most common cancer $(54 / 58,93 \%)$. The data were updated 2 years later after the sample size had reached 400. Eighty percent of the patients were females, and the younger the patients were the lower was the percentage of paraneoplastic syndrome. About $60 \%$ of the patients above 18 years had cancer. ${ }^{[18]}$

Incidence of anti-NMDAR encephalitis in China is unknown, too. From all the 32 cases reported with details and 3 patients of ours, we found $80 \%$ (28/35) of them are females, and the mean age is $19.8 \pm 9.7$ years. About 40\% (14/35) are reported with teratoma [Table 1]. Maybe, the gender ratio and age pattern of this disease in China described by Ren et al. ${ }^{[37]}$ are more precise because of their bigger pool of patients.

\section{Symptoms and signs}

The most common symptoms include mental disorders, memory loss, decrease in consciousness, movement disorders, seizures, autonomic nerve symptoms, and hypoventilation. ${ }^{[38]}$ Most of these symptoms are associated with pathological changes in brain function.

\section{Examination}

Half of the patients with anti-NMDAR encephalitis had no abnormalities in magnetic resonance imaging (MRI), while others had obvious changes in hippocampus, cerebellum, cortex, frontal lobe, insular lobe, basal ganglia, brain stem, and medulla. Multifocal metabolic abnormalities were found in the cortex or beneath the cortex in positron emission tomography or single-photon emission computed tomography tests. Low perfusion in frontal lobe and brain atrophy could be seen in some patients, which reversed in follow-ups, 5-7 years later. ${ }^{[18,39]}$

Majority of the patients had slow waves in electroencephalography (EEG), and continuous $\delta-\theta$ rhythms predominated the tension episode of anti-NMDAR encephalitis. These slow waves were not accompanied by abnormal movements, and did not react to anti-epileptic drugs. Video EEG should be involved in diagnosis and treatment. ${ }^{[18,40]}$

Cerebrospinal fluid samples of all patients were abnormal. Lymphocytes and quantity of protein in CSF increased in $80 \%$ of the patients at an early stage. Oligoclonal bands appeared in $60 \%$ of patients, and intrathecal synthesis of anti-NMDAR antibody could be detected in most patients. In the long-term follow-up patients, the titer of anti-NMDAR antibody in serum was still high, while it could not be detected in CSF. Because of the linear correlation between the loss of NMDAR in synapse and the titer of anti-NMDAR antibody in CSF, the latter is considered to be one of the definitive diagnostic criteria. ${ }^{[41,42]}$

All the reported Chinese patients showed positive results for antibody detection. Some of the patients had a high signal in fluid-attenuated inversion recovery and T2 of MRI, while others showed extreme $\delta$ brush wave. Similar findings were observed in patients abroad. ${ }^{[29]}$

\section{Diagnostic criteria and methods}

The emerging neuropsychiatric symptoms and anti-NMDAR antibodies in serum or CSF are accepted as diagnostic criteria for anti-NMDAR encephalitis. ${ }^{[16]}$ Detection of anti-NMDAR antibody includes two necessary methods: immunochemistry with rat hippocampus (and cerebellum) neurons, and genetically engineered HEK 293 cells expressing NMDAR on the surface. ${ }^{[14]}$ Antibody in CSF has higher sensitivity for diagnosis as compared to blood. ${ }^{[41]}$

Assay kits for detecting anti-NMDAR antibody are provided by EUROIMMUN Corporation. According to 


\begin{tabular}{|c|c|c|c|c|c|c|c|c|c|c|c|}
\hline Patient & Sex & Age & Teratoma & Surgery & Glucocorticoids & IVlg & $\begin{array}{l}\text { Serum } \\
\text { exchange }\end{array}$ & Rituximab & $\begin{array}{l}\text { Anti- } \\
\text { virus }\end{array}$ & Prognosis & Author \\
\hline 1 & Female & 13 & No & $\mathrm{N} / \mathrm{A}$ & Yes & Yes & - & - & - & $\begin{array}{l}\text { Completely } \\
\text { normal }\end{array}$ & Hu et al..$^{[24]}$ \\
\hline 2 & Female & 13 & No & $\mathrm{N} / \mathrm{A}$ & Yes & Yes & - & - & Yes & $\begin{array}{l}\text { Completely } \\
\text { normal }\end{array}$ & \\
\hline 3 & Female & 25 & Yes & Yes & Yes & Yes & - & - & Yes & $\begin{array}{l}\text { Completely } \\
\text { normal }\end{array}$ & \\
\hline 4 & Female & 19 & Yes & Yes & - & - & - & - & - & Self-maintenance & Chen et al. ${ }^{[25]}$ \\
\hline 5 & Female & 35 & Yes & Yes & - & Yes & - & - & - & $\begin{array}{l}\text { Near } \\
\text { self-maintenance }\end{array}$ & Chen et al. ${ }^{[26]}$ \\
\hline 6 & Female & 25 & No & $\mathrm{N} / \mathrm{A}$ & Yes & No & - & - & Yes & $\begin{array}{l}\text { Obviously } \\
\text { improved }\end{array}$ & Song and $\mathrm{Liu}^{[27]}$ \\
\hline 7 & Female & 22 & Yes & Yes & No & Yes & - & - & No & $\begin{array}{l}\text { Obviously } \\
\text { improved }\end{array}$ & \\
\hline 8 & Male & 18 & No & $\mathrm{N} / \mathrm{A}$ & Yes & No & - & - & Yes & $\begin{array}{l}\text { Obviously } \\
\text { improved }\end{array}$ & \\
\hline 9 & Male & 15 & No & $\mathrm{N} / \mathrm{A}$ & Yes & No & - & - & Yes & $\begin{array}{l}\text { Obviously } \\
\text { improved }\end{array}$ & \\
\hline 10 & Female & 30 & No & $\mathrm{N} / \mathrm{A}$ & Yes & Yes & Yes & - & Yes & Unfavorable & \\
\hline 11 & Female & 18 & No & $\mathrm{N} / \mathrm{A}$ & Yes & No & - & - & Yes & $\begin{array}{l}\text { Obviously } \\
\text { improved }\end{array}$ & \\
\hline 12 & Female & 26 & Yes & Yes & Yes & Yes & - & - & Yes & Death & \\
\hline 13 & Female & 16 & No & $N / A$ & No & Yes & - & - & Yes & Self-maintenance & Xu et al..[28] \\
\hline 14 & Male & 12 & No & $\mathrm{N} / \mathrm{A}$ & Yes & Yes & - & Yes & - & $\begin{array}{l}\text { Favorable and } \\
\text { no recurrence }\end{array}$ & Lu et al. ${ }^{[29]}$ \\
\hline 15 & Male & 23 & No & $\mathrm{N} / \mathrm{A}$ & Yes & Yes & - & - & - & $\begin{array}{l}\text { Recurrence, but } \\
\text { improved after } \\
\text { IVIg again }\end{array}$ & \\
\hline 16 & Female & 22 & No & $\mathrm{N} / \mathrm{A}$ & Yes & Yes & - & - & - & $\begin{array}{l}\text { Continuous } \\
\text { stupor-like state }\end{array}$ & \\
\hline 17 & Female & 22 & Yes & Yes & - & Yes & - & - & - & $\begin{array}{l}\text { Favorable and } \\
\text { no recurrence }\end{array}$ & \\
\hline 18 & Female & 26 & Yes & Yes & - & Yes & - & - & - & $\begin{array}{l}\text { Favorable and } \\
\text { no recurrence }\end{array}$ & \\
\hline 19 & Female & 28 & Yes & Yes & - & Yes & - & - & - & $\begin{array}{l}\text { Favorable and } \\
\text { no recurrence }\end{array}$ & \\
\hline 20 & Female & 17 & No & $\mathrm{N} / \mathrm{A}$ & No & Yes & - & - & - & $\begin{array}{l}\text { Favorable and } \\
\text { no recurrence }\end{array}$ & Wei et al. ${ }^{[30]}$ \\
\hline 21 & Female & 24 & Yes & No & Yes & Yes & - & - & - & $\begin{array}{l}\text { Favorable and } \\
\text { no recurrence }\end{array}$ & Wu et al..$^{[31]}$ \\
\hline 22 & Female & 30 & Yes & Yes & Yes & Yes & - & - & - & $\begin{array}{l}\text { Favorable and } \\
\text { no recurrence }\end{array}$ & Peng et al. ${ }^{[32]}$ \\
\hline 23 & Female & 6 & No & $\mathrm{N} / \mathrm{A}$ & - & Yes & - & Yes & - & $\begin{array}{l}\text { Favorable and } \\
\text { no recurrence }\end{array}$ & Wang et al. ${ }^{[33]}$ \\
\hline 24 & Male & 9 & No & $\mathrm{N} / \mathrm{A}$ & - & Yes & Yes & - & - & $\begin{array}{l}\text { Favorable and } \\
\text { no recurrence }\end{array}$ & \\
\hline 25 & Male & 15 & No & $\mathrm{N} / \mathrm{A}$ & - & Yes & - & - & - & $\begin{array}{l}\text { Favorable and } \\
\text { no recurrence }\end{array}$ & \\
\hline 26 & Female & 11 & No & $\mathrm{N} / \mathrm{A}$ & - & Yes & - & - & - & $\begin{array}{l}\text { Favorable and } \\
\text { no recurrence }\end{array}$ & \\
\hline 27 & Male & 8 & No & $\mathrm{N} / \mathrm{A}$ & - & Yes & - & - & - & $\begin{array}{l}\text { Favorable and } \\
\text { no recurrence }\end{array}$ & \\
\hline 28 & Female & 7 & No & $\mathrm{N} / \mathrm{A}$ & - & Yes & - & - & - & $\begin{array}{l}\text { Favorable and } \\
\text { no recurrence }\end{array}$ & \\
\hline 29 & Female & 7 & No & $\mathrm{N} / \mathrm{A}$ & Yes & Yes & - & - & - & $\begin{array}{l}\text { Favorable and } \\
\text { no recurrence }\end{array}$ & \\
\hline 30 & Male & 9 & No & $\mathrm{N} / \mathrm{A}$ & - & Yes & - & - & - & $\begin{array}{l}\text { Favorable and } \\
\text { no recurrence }\end{array}$ & Zhang et al. ${ }^{[34]}$ \\
\hline 31 & Female & 17 & Yes & Yes & - & Yes & - & - & - & $\begin{array}{l}\text { Favorable and } \\
\text { no recurrence }\end{array}$ & Shang et al. ${ }^{[35]}$ \\
\hline 32 & Female & 17 & Yes & Yes & Yes & Yes & - & - & - & $\begin{array}{l}\text { Favorable and } \\
\text { no recurrence }\end{array}$ & $\mathrm{Xu}$ et $a{ }^{[36]}$ \\
\hline 33 & Female & 45 & No & $\mathrm{N} / \mathrm{A}$ & - & Yes & - & - & - & $\begin{array}{l}\text { Favorable and } \\
\text { no recurrence }\end{array}$ & Our case \\
\hline
\end{tabular}

Contd... 


\begin{tabular}{|c|c|c|c|c|c|c|c|c|c|c|c|}
\hline Patient & Sex & Age & Teratoma & Surgery & Glucocorticoids & IVIg & $\begin{array}{l}\text { Serum } \\
\text { exchange }\end{array}$ & Rituximab & $\begin{array}{l}\text { Anti- } \\
\text { virus }\end{array}$ & Prognosis & Author \\
\hline 34 & Female & 47 & Yes & No & Yes & No & - & - & - & $\begin{array}{l}\text { Favorable and } \\
\text { no recurrence }\end{array}$ & Our case \\
\hline 35 & Female & 17 & Yes & Yes & - & Yes & - & - & - & $\begin{array}{l}\text { Favorable and } \\
\text { no recurrence }\end{array}$ & Our case \\
\hline
\end{tabular}

IVIg: Intravenous immunoglobulin; N/A: Not applicable; “-”: Not mentioned by author

our investigation, the mean price of an antibody test is about 60 dollars for the reported patients in China.

\section{Treatment}

Regarding to the treatment for anti-NMDAR encephalitis, Dalmau et al. ${ }^{[18]}$ provided a treatment proposal for this disease in 2011 [Figure 1]. They prefer concurrent intravenous immunoglobulin (IVIg) $(0.4 \mathrm{~g} / \mathrm{kg} / \mathrm{day}$ for 5 days) and methylprednisolone ( $1 \mathrm{~g} /$ day for 5 days) to plasma exchange. As for the second-line therapy, they often use rituximab combined with cyclophosphamide in adults. And in children, they often use only one of these drugs - mostly rituximab. In China, anti-NMDAR encephalitis as a new disease, is often confused with viral encephalitis, and is treated with acyclovir or/and virazole. When the diagnosis was uncertain, some doctors gave IVIg as an alternative to the patients who did not respond to anti-viral treatment. Rituximab was seldom used for anti-NMDAR encephalitis patients due to its high cost, and lack of doctor's experience with the drug [Table 1].

\section{Prognosis}

Gresa-Arribas et al. ${ }^{[41]}$ conducted a 5-year study with 501 patients. Their findings include: (1) $81 \%$ of anti-NMDAR encephalitis patients had favorable outcomes from immunotherapy, and factors affecting these outcomes include early diagnosis and nonintensive care unit treatment; (2) risk of recurrence is about $12 \%$ within 2 years, of which $67 \%$ is less harmful as compared with the first outbreak; (3) normally, the second-line immunotherapy was effective when the first-line therapy had failed. ${ }^{[41]}$ Based on the long-term follow-up, the higher titer of antibody in patients' serum or CSF, worse was the prognosis. There was significant association between CSF antibody titer and the risk of recurrence. ${ }^{[42]}$

Among the 35 patients with anti-NMDAR encephalitis, one patient was in a continuous stupor-like state, one patient died 4 days after the tumor removal, one patient had an unfavorable prognosis, one patient recurred but improved after IVIg again, and 30 patients (86\%) had favorable prognosis without recurrence or sequel [Table 1].



Figure 1: Proposed algorithm for the treatment of anti-N-methyl-D-aspartate receptors encephalitis

\section{OTHER ISSUES RELATED TO ANTI-NMDA RECEPTOR ENCEPHALITIS}

\section{Pregnancy}

Majority of the patients are females, and the issue of pregnancy is unavoidable. Pregnant patients could deliver a healthy baby if they have no NMDAR antibody in their serum. The curative effect increases significantly after giving birth or after termination of pregnancy.

\section{Synaptic autoimmune encephalopathy}

Some types of autoimmune encephalitis, such as anti-NMDAR encephalitis, anti-AMPAR encephalitis, anti-GABABR encephalitis, and anti-LGI1 encephalitis, can be distinguished by the antibodies against the receptors anchored in synapses. There are some common features of these diseases: high incidence in females always associated with tumor, psychiatric disorders, behavioral changes, and refractory seizures. Importantly, these diseases are reversible and curable with immunotherapy and removal of possible tumors, if they are diagnosed at an early stage.

The term of synaptic autoimmune encephalopathy is recommended for labeling these disease, thereby hinting at their favorable prognosis and the necessity for early immunotherapy. 


\section{SUMMARY AND FUTURE DIRECTIONS}

As compared to patients abroad, Chinese patients normally have a long course of recovery. There are several reasons for this, including inadequate laboratory techniques, absence of standard operating procedures for such type of treatment, insufficient drug treatment, less experience in second-line treatment, and noncompliance of treatment from time to time. This is a big challenge routinely faced by the neurologists in checkups, diagnosis, or treatment.

Viral encephalitis and anti-NMDAR encephalitis have similar clinical symptoms such as headache, fever, mental disorder and seizures, and similar observations in MRI or EEG. It has not been aligned whether glucocorticoid should be used in the early treatment of viral encephalitis. With the incidence of autoimmune encephalopathies rising, we propose that patients with unconfirmed encephalitis could use glucocorticoid once they have a CSF puncture, and IVIg can also be administered.

B-lymphocyte depletion therapy mediated by anti-CD20 monoclonal antibody has been a brilliant breakthrough in the treatment of various antibody-related autoimmune diseases, such as anti-NMDAR encephalitis, rheumatoid arthritis, etc. It is important to investigate the possibility of applying this therapy to other higher-incidence neural autoimmune diseases, such as ophthalmoneuromyelitis. The vista is optimistic.

\section{REFERENCES}

1. Lipton SA. Paradigm shift in neuroprotection by NMDA receptor blockade: memantine and beyond. Nat Rev Drug Discov 2006;5:160-70.

2. Dingledine R, Borges K, Bowie D, Traynelis SF. The glutamate receptor ion channels. Pharmacol Rev 1999;51:7-61.

3. Cull-Candy SG, Leszkiewicz DN. Role of distinct NMDA receptor subtypes at central synapses. Sci STKE 2004;2004:re16.

4. Wolosker H. D-serine regulation of NMDA receptor activity. Sci STKE 2006;2006:pe41.

5. McRoberts JA, Coutinho SV, Marvizón JC, Grady EF, Tognetto M, Sengupta JN, Ennes HS, Chaban VV, Amadesi S, Creminon C, Lanthorn T, Geppetti P, Bunnett NW, Mayer EA. Role of peripheral $\mathrm{N}$-methyl-D-aspartate (NMDA) receptors in visceral nociception in rats. Gastroenterology 2001;120:1737-48.

6. Suen PC, Wu K, Xu JL, Lin SY, Levine ES, Black IB. NMDA receptor subunits in the postsynaptic density of rat brain: expression and phosphorylation by endogenous protein kinases. Brain Res $\mathrm{Mol}$ Brain Res 1998;59:215-28.

7. Gladding CM, Raymond LA. Mechanisms underlying NMDA receptor synaptic/extrasynaptic distribution and function. Mol Cell Neurosci 2011;48:308-20.

8. Harris AZ, Pettit DL. Recruiting extrasynaptic NMDA receptors augments synaptic signaling. J Neurophysiol 2008;99:524-33.
9. Berberich S, Jensen V, Hvalby $\varnothing$, Seeburg PH, Köhr G. The role of NMDAR subtypes and charge transfer during hippocampal LTP induction. Neuropharmacology 2007;52:77-86.

10. Waxman EA, Lynch DR. N-methyl-D-aspartate receptor subtypes: multiple roles in excitotoxicity and neurological disease. Neuroscientist 2005; 11:37-49.

11. Coyle JT. Glutamate and schizophrenia: beyond the dopamine hypothesis. Cell Mol Neurobiol 2006;26:365-84.

12. Ruscheweyh R, Wilder-Smith O, Drdla R, Liu XG, Sandkühler J. Long-term potentiation in spinal nociceptive pathways as a novel target for pain therapy. Mol Pain 2011;7:20.

13. Gultekin SH, Rosenfeld MR, Voltz R, Eichen J, Posner JB, Dalmau J. Paraneoplastic limbic encephalitis: neurological symptoms, immunological findings and tumour association in 50 patients. Brain 2000;123:1481-94.

14. Vitaliani R, Mason W, Ances B, Zwerdling T, Jiang Z, Dalmau J. Paraneoplastic encephalitis, psychiatric symptoms, and hypoventilation in ovarian teratoma. Ann Neurol 2005;58:594-604.

15. Dalmau J, Tüzün E, Wu HY, Masjuan J, Rossi JE, Voloschin A, Baehring JM, Shimazaki H, Koide R, King D, Mason W, Sansing LH, Dichter MA, Rosenfeld MR, Lynch DR. Paraneoplastic anti-N-methyl-D-aspartate receptor encephalitis associated with ovarian teratoma. Ann Neurol 2007;61:25-36.

16. Dalmau J, Gleichman AJ, Hughes EG, Rossi JE, Peng X, Lai M, Dessain SK, Rosenfeld MR, Balice-Gordon R, Lynch DR. Anti-NMDA-receptor encephalitis: case series and analysis of the effects of antibodies. Lancet Neurol 2008;7:1091-8.

17. Zhou SN, Fu XX, Liu YM, Cao LL, Wang B, Li JJ, Li Y, Gao YJ, Gong XP. Analyse of one case of paraneoplastic limbic encephalitis related with ovary teratoma. Chin J Neurol 2009;42:686-8. (in Chinese)

18. Dalmau J, Lancaster E, Martinez-Hernandez E, Rosenfeld MR, Balice-Gordon R. Clinical experience and laboratory investigations in patients with anti-NMDAR encephalitis. Lancet Neurol 2011;10:63-74.

19. Lai M, Hughes EG, Peng X, Zhou L, Gleichman AJ, Shu H, Matà S, Kremens D, Vitaliani R, Geschwind MD, Bataller L, Kalb RG, Davis R, Graus F, Lynch DR, Balice-Gordon R, Dalmau J. AMPA receptor antibodies in limbic encephalitis alter synaptic receptor location. Ann Neurol 2009;65:424-34.

20. Lancaster E, Lai M, Peng X, Hughes E, Constantinescu R, Raizer J, Friedman D, Skeen MB, Grisold W, Kimura A, Ohta K, lizuka T, Guzman M, Graus F, Moss SJ, Balice-Gordon R, Dalmau J. Antibodies to the GABA (B) receptor in limbic encephalitis with seizures: case series and characterisation of the antigen. Lancet Neurol 2010;9:67-76.

21. Lai M, Huijbers MG, Lancaster E, Graus F, Bataller L, Balice-Gordon R, Cowell JK, Dalmau J. Investigation of LGI1 as the antigen in limbic encephalitis previously attributed to potassium channels: a case series. Lancet Neurol 2010;9:776-85.

22. Prüss H, Dalmau J, Harms L, Höltje M, Ahnert-Hilger G, Borowski K, Stoecker W, Wandinger KP. Retrospective analysis of NMDA receptor antibodies in encephalitis of unknown origin. Neurology 2010;75:1735-9.

23. Granerod J, Ambrose HE, Davies NW, Clewley JP, Walsh AL, Morgan D, Cunningham R, Zuckerman M, Mutton KJ, Solomon T, Ward KN, Lunn MP, Irani SR, Vincent A, Brown DW, Crowcroft NS; UK Health Protection Agency (HPA) Aetiology of Encephalitis Study Group. Causes of encephalitis and differences in their clinical presentations in England: a multicentre, population-based prospective study. Lancet Infect Dis 2010;10:835-44.

24. Hu XS, Ouyang M, Li H, Li DF, Dou WB, Wu XY, Chen W, Xu SQ. Three cases of anti-NMDA receptor encephalitis. Chin $J$ Neuroimmunol Neurol 2014;21:66-8. (in Chinese)

25. Chen L, Zhu FQ, Zhu JH, Li XL. Anti-NMDA receptor encephalitis: 
a case report and literature review. $J$ Apoplexy Nervous Dis 2014;31:170-1. (in Chinese)

26. Chen W, Chen QX, Wang L. Anti-NMDAR antibody encephalitis with bilateral ovarian teratoma: a case report. $J$ Endocr Surg 2013;7:521-2. (in Chinese)

27. Song L, Liu AH. Anti-N-methyl-D-aspartic acid receptor encephalitis: clinical analysis of 7 cases. Natl Med J China 2013;93:2508-10. (in Chinese)

28. Xu YY, Liu Q, Peng B, Cui LY. A 16-year-old woman with fever, epilepsy and diplopia. Chin J Contemp Neurol Neurosurg 2013;13:544-9. (in Chinese)

29. Lu Q, Guan HZ, Ren HT, Niu JW, Sun Q, Huang XR, Wang L, Liu T, Yuan J. Analysis of three cases of anti-N-Methyl-D-aspartate receptor encephalitis without tumor. Chin J Neurol 2013;46:315-9. (in Chinese)

30. Wei X, Wu Y, Li LJ, Huang JS, Ren HT. Anti-N-methyl-D-aspartate receptor encephalitis: a case report. J Clin Electroneurophysiology 2013;22:319-20. (in Chinese)

31. Wu Y, Chen X, Tan H, Li XG. Anti-N-methyl-D-aspartate receptor encephalitis: a case report and literature review. Chin J Pract Nervous Dis 2013;16:81-2. (in Chinese)

32. Peng F, Sun TW, Zhang XJ, Wu Q, Ma SC, Lu NN, Yang F, Xu QY, Wang HX. Diagnosis and treatment of anti-N-methyl-D-aspartate receptor encephalitis. Chin JEmerg Med 2013;22:1432-4. (in Chinese)

33. Wang XH, Fang F, Ding CH, Lü JL, Han TL, Liu LY, Li JW, Wu Y, Cui LY, Ren HT, Xu CL. Anti-N-methyl-D-aspartate receptor encephalitis in seven children. Chin J Pediatr 2012;50:885-9. (in Chinese)

34. Zhang X, Xiong H, Ji TY, Zhang YH, Wang Y. Case report of anti-N-methyl-D-aspartate receptor encephalitis in child. J Appl Clin Pediatr 2012;27:1903-7. (in Chinese)

35. Shang M, Hao ZP, Jin JY. Paraneoplastic anti-NMDA receptor antibody paraneoplastic limbic encephalitis induced by ovarian immature teratoma: a case report. Chin J Clin Obstet Gynecol
2011;12:388-9. (in Chinese)

36. Xu CL, Zhao WQ, Li JM, Wang JW, Wang SH, Wang DX, Liu MY, Qiao SS, Jin JY, Hao ZP, Ji XJ. Anti-N-methyl-D-aspartate receptor encephalitis: an adolescent with ovarian teratoma. Chin J Neurol 2010;43:781-3. (in Chinese)

37. Ren HT, Cui LY, Guan HZ, Yuan J, Lu Q, Qian M, Liu Q, Chen L, Fang F. Screening and diagnosis of anti-N-methyl-D-aspartate receptor encephalitis in encephalitis of unknown origin. Chin JNeurol 2014;47:119-22. (in Chinese)

38. Iizuka T, Sakai F, Mochizuki H. Update on anti-NMDA receptor encephalitis. Brain Nerve 2010;62:331-8. (in Japanese)

39. Chan SH, Wong VC, Fung CW, Dale RC, Vincent A. Anti-NMDA receptor encephalitis with atypical brain changes on MRI. Pediatr Neurol 2010;43:274-8.

40. da Silva-Júnior FP, Castro LH, Andrade JQ, Bastos CG, Moreira CH, Valério RM, Jorge CL, Marchiori PE, Nitrini R, Garzon E. Serial and prolonged EEG monitoring in anti-N-Methyl-D-Aspartate receptor encephalitis. Clin Neurophysiol 2014;DOI: 10.1016/j. clinph.2014.01.001.

41. Gresa-Arribas N, Titulaer MJ, Torrents A, Aguilar E, McCracken L, Leypoldt F, Gleichman AJ, Balice-Gordon R, Rosenfeld MR, Lynch D, Graus F, Dalmau J. Antibody titres at diagnosis and during follow-up of anti-NMDA receptor encephalitis: a retrospective study. Lancet Neurol 2014;13:167-77.

42. Frechette ES, Zhou L, Galetta SL, Chen L, Dalmau J. Prolonged follow-up and CSF antibody titers in a patient with anti-NMDA receptor encephalitis. Neurology 2011;76:S64-6.

Cite this article as: Li L, Wang CB, Zhao G. Anti-N-methyl-D-aspartate recepto encephalitis in China. Neuroimmunol Neuroinflammation 2014;1(1):17-23.

Source of Support: Nil. Conflict of Interest: No.

Received: 06-05-2014; Accepted: 26-05-2014 